\title{
The National Character Education Paradigm in the Indonesian Language Instructions
}

\author{
Isah Cahyani \\ Universitas Pendidikan Indonesia, Bandung, Indonesia
}

\begin{abstract}
The cultural-based nation character education in the elementary school is aimed at implementing the education in its nature that is developing the human potential of students for their roles in the future. This national character education integratively combines the generic and specific potentials to solve and to face the problems of life. The value-based life-skills education in the elementary school is underlying the behaviour, characteristics, and attitude that is based on the succeed of students' future life. The giving of universal values such as honesty, respect, manners, hardworking, tolerance, and others become the core study for teachers' insights during their friendly interaction with students, for that reason, education in schools are so consciously designed and managed that the instructional process for students evoke the attitude and behaviour learning through the nation character education.

Many inhibition factors that are faced by the school in implementing the education, internally in the school or externally especially in understanding and teacher's competence in developing nation character education. It is all because not only a simple thing to change teachers' paradigm in implementing the managing model of conventional learning that been rooted in their teaching attitude. The finding shows that (1) according to the analysis of Indonesian Language SK-KD, the national characters evoke in terms of loving to read, patriotism, respecting others, tolerance, friendship, caring for others, communicative, religious, honesty, discipline, creative, perseverance, confidence, curiosity, bravery, and critical; (2) the character values are not explicitly stated yet in the Lesson Plan for many kinds of elementary schools; (3) in the religion- and multicultural-based schools, the character implementation has been planned and accustomed in the class and school environment; (4) in the religion- and multicultural-based schools, teachers' behaviour in implementing the character values is routinely done, conditioned, and customization. The research was held in four elementary schools in Bandung that were set purposively, by considering the paradigm, the school vision and mission, including the conventional elementary school (Pasirkaliki), religion-based elementary school (Muhammadiyah), potential elementary school (Sukarasa), and Multicultural elementary school (Slamet Riyadi). The research was focused on the analysis of SK-KD, Lesson Plan, and learning observation as well as interviewing the teachers.
\end{abstract}

Keywords: paradigm, developing, education, values, and character.

\section{INTRODUCTION}

Globalization presents many demands and changes in many life patterns and attitudes. The impact evokes social crisis. This crisis can be tension, pressure, frustration, and the uncertainty in the society. It is like the excessive demonstration gives the euphoria, the Representatives quarrel, students quarrel, and other criminal deeds. It is worried that the impact will be the decreasing of society cares in interaction. The fact shows "the loss" of individual identity of Indonesian that results in the decreasing and loss of Indonesian characters and national identity. When the character is lost, everything is lost, says a wise word. Definitely, new technology and science advancement will be followed by the change of attitude. Consequently, people are demanded to be sensitive to changes in the society as well as improve the negative attitudes towards humans' relation.

Balitbang (2010) states that this cultural and national character issues now become the great attention of people. This attention is in terms of many aspects of life, written in the media, interviews, dialogues, and talk show in the television. Besides, in the mass media, social leader, experts, and education analysts, as well as social analysts talk about these issues in many seminar forums, locally, nationally, and even internationally. The issues appear in the society such as corruption, harshness, sexual abuse, damaging, mass quarrel, consumptive economy, not productive politic life, and other issues that become the heat discussion in the mass media, seminars, and other occasions. Many solving alternatives are proposed such as rules, constitution, increasing law reinforcement and implementation.

The effect of the issues definitely affects the education. By education, it is expected to give an effective way to stabilize those negative things. Here comes a time for education to rise facilitating the revitalization process of life attitudes in the society to get maximum benefits. Education is known to have an important role in the development process of the nation in order to avoid from many pressures of today's modern life. Education is expected to decrease the social crisis by stabilizing emotions, improving relationship, attitudes, and habits that have damaged the social relationship as well as improving social's behaviour in anticipating the characters destruction.

In this case, education is considered as the preventive alternative because education develops new generation for the better nation. As a preventive alternative, education is expected to develop the quality of young generation in many aspects that can decrease and reduce many issues related to the cultural and national problems. It is admitted that the education outcome will not be seen soon, but it has the endurance and strong impact on the society.

For that reason, the educational process through the learning process can take the advantages of Indonesian language as the component of developing national characters. As a saying goes, "Language shows nation." One of them is the integrated Indonesian language learning can be used as 
the process of developing characters in the increasing quality of national identity. Therefore, learning is not only in a class but also there is an extensive role in developing national character as the study laboratory. This thing is especially for the need of effective character education.

\section{DISCUSSION}

The learning process is aimed to improve students' capability in using appropriate Bahasa Indonesia both in written and spoken form as well as to enhance their appreciation of literary works in Bahasa Indonesia.

The basic competence in the learning of Bahasa Indonesia is a form of minimum standard qualification of students' capability describing their satisfaction and ability to use Bahasa Indonesia as well as positive attitude toward the language and its literature. The basic competence is the fundamental framework to understand and respond the domestic, national, and international issues.

With the existence of the basic competence in the learning of Bahasa Indonesia, certain objectives are established. They are as follow:

1) Students are able to develop their aptitude based on their competence, need, and interest. Furthermore, the students are also expected to improve their appreciation of their literary and intelligence work of their nation.

2) Teachers are able to concern their attention in improving students' skill in using Bahasa Indonesia by providing sufficient teaching media.

3) Teachers are more independent and free in determining language and literature teaching that go in hand with the school condition and the students' capability.

4) Parents and surrounding society can be actively involved in the conduct of the language and literature learning in the school.

5) Schools are able to design educational program for the learning of Bahasa Indonesia considering existing facilities and students' condition.

6) Local government can determine language and literature learning sources that are suitable with the local idiosyncrasy yet still concerning national importance.

In addition, the learning of Bahasa Indonesia is to equip students with the following skills:

1) Being able to communicate effectively and efficiently by considering existing norms either in written or spoken form.

2) Appreciating and feeling proud in using Bahasa Indonesia as the united and national language.

3) Comprehend and use Bahasa Indonesia accurately and creatively for any purposes.

4) Use Bahasa Indonesia to enhance intellectual capacity as well as emotional and social maturity.

5) Enjoy and use Indonesian literature to expand knowledge, refine attitude, and improve understanding and capability in using the language.

6) Appreciating and promoting Indonesian literature as national intellectual and cultural treasure.
Based on results of observations and interviews about teaching and learning Bahasa Indonesia.

\subsection{Indonesian Language and Literature Learning and Character Education}

According to the interviews, teachers already know about character education. They suggest that character education is an educational process that includes the implementing of the values associated with moral behaviour of the learners in the learning process. They define the character education as 15 values: religious, honesty, tolerance, discipline, hard work, creative, independent, curiosity, nationalism, patriotism, friendly/communicative, love peace, love to read.

Character education is closely related to Indonesian language. It appears on the teaching of language skills which include listening, speaking, reading, and writing. Characters that appear on learning Indonesian are especially on the learners who are taught how to speak Indonesian politely, correctly, with a good grammar. As for the interest, it goes more favor to the Indonesian language skills in accordance with the rules of ethics in speaking. However, there are some obstacles that students perceived mainly in speaking.

Implementation constraints sometimes get students who are less accustomed in using Indonesian properly and correctly. Nonetheless, students mostly like to write because they can be more creative and expressive.

\subsection{The Learning Implementation of Indonesian Language and Literature}

The results of interviews and observations show that teachers have implemented the character values; honesty, discipline, love to read, creative, religious, responsibility, appreciation, creative, and communicative in Indonesian language and literature learning, especially on Indonesian language and literature learning. These are correlated to the language skills. Character values can be implemented in four language skills such as reading skills. By knowing the aims of reading, the learners can enhance their knowledge. A character value that is implemented is to love reading. Tasks given that require learners to seek information from various sources readings will also implement the values of love to read.

A suitable method to link the two is the method of demonstration or performance. In the practice of character education, one of media that can be used is pictures. For example by choosing some pictures that imaging the character values. The media, therefore, is used in the learning of writing skills. Character appraisal is to provide an objective assessment and in accordance with the capabilities of the students.

Character values implemented by teachers in the learning process are according to the aims of Indonesian language and learning process which are hard work, creative, and appreciative. The aim of learning language is to enhance the language skills of the learners. Character value implemented to achieve the aim is the materials given in reading skills that 
are discourse based on local wisdom that can instill the nationalism and patriotism values to the learners.

\subsection{Observation Results in Teaching and Learning Process (PBM) of Indonesian Language and Character}

Teachers in this school have not stated yet the character values on their lesson plan of Indonesian language and literature explicitly, but they have done in the PBM. It appears form teachers' attitude and behaviour through the PBM is holding. Several character values that teachers implement are religious, independent, discipline, responsibility, care to others, honesty, hard work, love to read, appreciative. Teachers always ask the students to pray every beginning and the end of the class so that the knowledge they gain blessed by God. Teachers also teach students to care about the others and to help each other in difficult times. It is shown when the teacher asks student to lend his eraser to his friend who doesn't have an eraser.

PBM goes smoothly and orderly. This reflects that teacher has implemented the value of discipline to students. Teachers deliver the materials firmly and systematically. The materials are related to the listening skills. In the practice of listening, the teacher asks two of students to read a text in front of the class while the rest students are listening to it well and answering questions written in their LKS. It is done to implement the independent value to the students to encourage being brave to go to the front of the class.

Teacher asks the students to answer the questions relate to the text being told by the two students is aimed to implement the hard work value to the students so that they will try hard to get the best result. After this practice is done, the teacher asks students to assess their own work. It is purposed to implement the honesty value to them, justify the correct answer and dare to blame if the answer is wrong. After checking the answers together, the teacher asks who gets the highest and lowest score. The teacher praises a student who got the highest score and gives support to be more focus and keep learning for the student who got the lowest score. In addition, the teacher also appreciates every student's work by posting it on the wall of class.

In the end of PBM, students are asked to read a book they interested in. It's aimed to implement the love to read value since earlier starting with readings they like. The teacher ends the PBM by saying hamdalah together. Character value that has been implemented since the very start of the class is the teacher asks several students to clean the classroom before they go home or it is also called as daily cleaning officer. The task plays as a responsibility duty for them who use the class so they have to clean it back.

Character education seems to become one amidst the many responsibilities that must be fulfilled by the teachers to be applied to the students, especially at primary school level. Problems face everyday regarding juvenile delinquency to the macro level like the erosion of the ethics. That is why character education is important.
Character education according to the Curriculum Centre plays as an effort to develop character values of students to be their foundation of thinking, acting, and behave in developing themselves as a people in society and citizen in broad. Those character values are hoped to be able to differ Indonesian people with people from other countries.

\section{CONCLUSIONS}

Based on the analysis and discussion conducted at the beginning, this section will be presented at the conclusion of the research conducted. The conclusions are as followed:

1) The analysis of SK-KD obtained the mapping of character values contained. Those values include love reading, tolerance, friendship, caring, communicative, religious, honesty, discipline, creative, perseverance, selfconfidence, and critical resources.

2) Development of cultural education values and national character are integrated into every subject of every subject, including the Indonesian language.

3) Very strong character education in schools based on religious and multicultural. It can be perceived from a variety of school activities, classes, and the attitudes of teachers and principals. Planning and implementation of cultural education values and national character conducted by the principal, teachers, education personnel (counselor) together as a community educator and implemented it into the curriculum through conditioning, exemplary, and routines. The development of character education in schools and religionbased multicultural pursued through routine activities, exemplary, and conditioning.

\section{REFERENCES}

Balitbang, Puskur. 2010. Panduan Pendidikan Budaya dan Karakter Bangsa. Jakarta: Depdiknas. 